\title{
Antioxidant responses of Laeonereis acuta (Polychaeta) after exposure to hydrogen peroxide
}

\author{
C.E. da Rosa, A. Bianchini and J.M. Monserrat \\ Departamento de Ciências Fisiológicas, Programa de Pós-Graduação em Ciências Fisiológicas - \\ Fisiologia Animal Comparada, Fundação Universidade Federal do Rio Grande, Rio Grande, RS, Brasil
}

Correspondence to: J.M. Monserrat, Departamento de Ciências Fisiológicas, Programa de Pós-graduação em Ciências Fisiológicas - Fisiologia Animal Comparada, Fundação Universidade Federal do Rio Grande, A. Itália, km 8, Campus Carreiros, 96201-900 Rio Grande, RS, Brasil Fax: +55-53-3233-8680. E-mail: josemmonserrat@pesquisador.cnpq.br

\begin{abstract}
The effects of $\mathrm{H}_{2} \mathrm{O}_{2}$ were evaluated in the estuarine worm Laeonereis acuta (Polychaeta, Nereididae) collected at the Patos Lagoon estuary (Southern Brazil) and maintained in the laboratory under controlled salinity (10 psu diluted seawater) and temperature $\left(20^{\circ} \mathrm{C}\right)$. The worms were exposed to $\mathrm{H}_{2} \mathrm{O}_{2}(10$ and $50 \mu \mathrm{M})$ for 4,7 , and 10 days and the following variables were determined: oxygen consumption, catalase (CAT) and glutathione peroxidase activity in both the supernatant and pellet fractions of whole body homogenates. The concentrations of non-protein sulfhydryl and lipid peroxides (LPO) were also measured. The oxygen consumption response was biphasic, decreasing after 4 days and increasing after 7 and 10 days of exposure to $50 \mu \mathrm{M}$ $\mathrm{H}_{2} \mathrm{O}_{2}(\mathrm{P}<0.05)$. At the same $\mathrm{H}_{2} \mathrm{O}_{2}$ concentration, CAT activity was lower $(\mathrm{P}<0.05)$ in the pellet fraction of worms exposed for 10 days compared to control. Non-protein sulfhydryl concentration and glutathione peroxidase activity were not affected by $\mathrm{H}_{2} \mathrm{O}_{2}$ exposure. After 10 days, LPO levels were higher $(\mathrm{P}<0.05)$ in worms exposed to $50 \mu \mathrm{M} \mathrm{H}_{2} \mathrm{O}_{2}$ compared to control. The reduction in the antioxidant defense was paralleled by oxidative stress as indicated by higher LPO values ( $441 \%$ compared to control). The reduction of CAT activity in the pellet fraction may be related to protein oxidation. These results, taken together with previous findings, suggest that the worms were not able to cope with this $\mathrm{H}_{2} \mathrm{O}_{2}$ concentration.
\end{abstract}

Key words: Worms; Laeonereis acuta; Hydrogen peroxide; Oxidative stress; Antioxidant enzymes; Oxygen consumption

Research supported by FINEP (No. 23.01.0719.00), CNPq (No. 300536/90-9), and PGCF-FAC. C.E. da Rosa was the recipient of a CAPES fellowship. J.M. Monserrat and A. Bianchini are recipients of CNPq research fellowships.

Received March 16, 2007. Accepted October 18, 2007

Hydrogen peroxide $\left(\mathrm{H}_{2} \mathrm{O}_{2}\right)$ is a non-radical reactive oxygen species and the most stable intermediate in the four-electron reduction of $\mathrm{O}_{2}$ to water. In the aquatic environment, $\mathrm{H}_{2} \mathrm{O}_{2}$ predominantly derives from UV-driven photoactivation of dissolved organic matter (1). Since $\mathrm{H}_{2} \mathrm{O}_{2}$ is uncharged, it easily passes through cell membranes by diffusion, and when inside the cells it can react with transition metals liberating hydroxyl radicals $\left(\mathrm{HO}^{\bullet}\right)$ (2). At high concentrations, these radicals induce peroxidation of lipids and proteins, affecting cell integrity $(2,3)$.

Aquatic organisms have to cope with a wide variety of environmental pro-oxidants, as well as with those produced by normal aerobic metabolism, leading to the requirement of efficient antioxidant mechanisms. Aerobic cells have acquired a variety of antioxidant mechanisms, including enzymatic (superoxide dismutase, catalase (CAT), glutathione peroxidase (GPx)) and non-enzymatic (glutathione, carotenoids, $\alpha$-tocopherol, etc.) defenses (4). The existence of antioxidant defenses and oxidative stress generation under exposure to pro-oxidants such as $\mathrm{H}_{2} \mathrm{O}_{2}$ have been reported in marine organism, with an increase in lipid peroxide (LPO) content (1), induction of antioxidant 
enzymes (CAT, superoxide dismutase) (2) and a reduction in oxygen consumption $(2,4,5)$.

Since $\mathrm{H}_{2} \mathrm{O}_{2}$ is a conspicuous environmental pro-oxidant, the aim of the present study was to evaluate the effects of $\mathrm{H}_{2} \mathrm{O}_{2}$ exposure on oxygen consumption, on $\mathrm{H}_{2} \mathrm{O}_{2}$ detoxification enzymes in the pellet and supernatant fractions, non-protein sulfhydryl groups and oxidative damage (LPO) of the estuarine worm Laeonereis acuta (Polychaeta, Nereididae). The estuarine worm $L$. acuta has been widely employed in toxicological and environmental studies for analysis of their antioxidant and oxidative damage responses to copper, cadmium and cyanobacterium bloom events and in biomonitoring programs (6-9).

Specimens of L. acuta (60-120 mg) were collected in a salt marsh ("Saco do Justino") near Rio Grande city (Southern Brazil, $\left.32^{\circ} \mathrm{S}, 52^{\circ} \mathrm{W}\right)$. This site was reported to be unpolluted (6).

The organisms were maintained under laboratory conditions as previously described (10). Briefly, the worms were kept individually in glass dishes $(6.0 \mathrm{~cm}$ in diameter) containing a thin sand layer and approximately $100 \mathrm{~mL}$ of $10 \mathrm{psu}$ diluted seawater at $\mathrm{pH} 8.0,20^{\circ} \mathrm{C}$. The fixed photoperiod was a 12-h light:12-h dark cycle. During the acclimation period ( 5 days) the animals were fed frozen Artemia sp and $100 \%$ of the water was renewed every 2 days.

After the acclimation period the animals were divided into three groups: a control group exposed to diluted seawater (salinity = $10 \mathrm{psu} ; \mathrm{N}=60)$, and a second $(\mathrm{N}=60)$ and a third group $(\mathrm{N}=60)$ receiving diluted seawater (salinity $=10 \mathrm{psu}$ ) containing 10 and $50 \mu \mathrm{M}$ hydrogen peroxide, respectively. The condition was the same as employed in the acclimation period except for the absence of sand in dishes and for water renewal, which was done daily. No mortality was recorded during the experimental period.

At the end of the exposure period of 4,7 , and 10 days, some of the animals ( $N=10$ per experimental group) were used for the oxygen consumption assay and the remaining ones were frozen at $-70^{\circ} \mathrm{C}$ for later analyses.

For the determination of oxygen consumption (11) the animals were transferred to $10-\mathrm{mL}$ chambers containing 10 psu diluted seawater, $\mathrm{pH} 8.0$, at $20^{\circ} \mathrm{C}$. Oxygen consumption was recorded with a manual oximeter (DIGIMED, São Paulo, SP, Brazil). Values are reported as $\mathrm{mg} \mathrm{O}_{2} \mathrm{~h}^{-1} \mathrm{~g}$ wet weight ${ }^{-1}$.

For the enzymatic determinations (12), whole animals were homogenized with cold buffer $(1: 3, \mathrm{v} / \mathrm{v})$ containing $0.5 \mathrm{M}$ sucrose and $0.15 \mathrm{M} \mathrm{NaCl}$ in $20 \mathrm{mM}$ Tris- $\mathrm{HCl}$, $\mathrm{pH}$ 7.6. The homogenate was centrifuged at $500 \mathrm{~g}$ for $15 \mathrm{~min}$ at $4^{\circ} \mathrm{C}$ and the resulting supernatant was centrifuged at 12,000 $g$ for $30 \mathrm{~min}$ at $4^{\circ} \mathrm{C}$. The $12,000-g$ pellet (peroxisomal and mitochondrial fraction) was resuspended with the homogenization buffer in the same volume as employed for homogenization. Both extracts (supernatant of $12,000 \mathrm{~g}$ and the resuspended pellet) were used for the determination of CAT and GPx activity since CAT activity is expected to occur only in the pellet fraction and GPx activity in the cytosolic fraction.

CAT activity was measured as the rate of enzymatic decomposition of $\mathrm{H}_{2} \mathrm{O}_{2}$ monitored as a decrease of absorbance at $240 \mathrm{~nm}$ (13). Enzyme activity is reported as CAT units, with one unit being the amount of enzyme needed to hydrolyze $1 \mu \mathrm{mol} \mathrm{H}_{2} \mathrm{O}_{2}$ min $^{-1} \mathrm{mg}$ protein ${ }^{-1}$ at $30^{\circ} \mathrm{C}$ and $\mathrm{pH}$ 8.0. GPx-Se activity (14) was measured as NADPH oxidation measured at $340 \mathrm{~nm}$ in the presence of excess glutathione reductase, reduced glutathione, $\mathrm{H}_{2} \mathrm{O}_{2}$, and aliquots of the homogenate. The results are reported as GPx units, with one unit being the amount of enzyme necessary to oxidize $1 \mu \mathrm{mol}$ NADPH $\min ^{-1} \mathrm{mg} \mathrm{protein}^{-1}$ at $30^{\circ} \mathrm{C}$ and $\mathrm{pH} 7.2$.

For the measurement of non-protein sulfhydryl groups (NP-SH) (15), tissues were homogenized (1:20) in $20 \mathrm{mM}$ EDTA. NP-SH content was measured after deproteinization with $50 \%$ trichloroacetic acid. NP-SH were detected using 5,5-dithiobis(2-nitrobenzoic acid) and absorbance at 405 $\mathrm{nm}$ was determined in a microplate reader. The result was divided by the protein concentration of each sample prior to deproteinization and is reported as specific activity, $\eta$ mol glutathione/mg protein.

LPO was measured by the Fox method (16) based on $\mathrm{Fe}^{2+}$ oxidation by lipid hydroperoxides (FOX reactive substances) at acid $\mathrm{pH}$ in the presence of the $\mathrm{Fe}^{3+}$-complexing dye xylenol orange. Samples were homogenized (1:9) in $100 \%$ cold $\left(4^{\circ} \mathrm{C}\right)$ methanol. The homogenate was centrifuged at $1000 \mathrm{~g}$ for $10 \mathrm{~min}$ at $4^{\circ} \mathrm{C}$ and the supernatant was collected and used for LPO determination (580 nm). Cumene hydroperoxide was employed as standard. The results are reported as $\eta \mathrm{mol}$ cumene hydroperoxide/g tissue.

Significant differences between treatments were assessed by ANOVA in combination with the Newman-Keuls a posteriori test, with the level of significance set at $5 \%$.

Several studies have demonstrated that when marine invertebrates are exposed to $\mathrm{H}_{2} \mathrm{O}_{2}$ the main response observed is an increased activity of the enzymes responsible for the detoxification of $\mathrm{H}_{2} \mathrm{O}_{2}$, i.e., CAT and/or GPx. This result was observed in shrimp (2), worms (4) and mussels (12). In contrast, $L$. acuta did not present antioxidant responses to $\mathrm{H}_{2} \mathrm{O}_{2}$ exposure (5). However, the objective of the present study was to observe the activity patterns of both enzymes in the pellet and supernatant fractions, since CAT is a well-known peroxisomal enzyme (3). 
The presence of CAT activity in the supernatant fraction would be related to peroxisome damage during homogenization (12). Concerning CAT activity, no statistical difference $(P>0.05)$ was observed in the supernatant fraction (Figure 1A), whereas a lower CAT activity $(P<0.05)$ was observed in the pellet fraction of worms exposed to $50 \mu \mathrm{M}$ $\mathrm{H}_{2} \mathrm{O}_{2}$ for 10 days (Figure 1B). The other enzyme that degrades $\mathrm{H}_{2} \mathrm{O}_{2}$, GPx, was not affected by exposure to this oxidant either in the supernatant or in the pellet fraction ( $P$ $>0.05$; Figure $1 \mathrm{C}$ and $\mathrm{D}$ ). The other antioxidant mechanism analyzed, NP-SH content, was not affected by $\mathrm{H}_{2} \mathrm{O}_{2}$ exposure $(P>0.05)$. The mean values $( \pm$ SEM) after 7 days of exposure were $2.5 \pm 0.5,2.1 \pm 0.7$, and $2.5 \pm 0.3$ $\mathrm{nmol} / \mathrm{mg}$ protein for the control and 10 and $50 \mu \mathrm{M} \mathrm{H}_{2} \mathrm{O}_{2}$ groups, respectively.

The absence of the induction of CAT and GPx activity induction does not mean that the animal is vulnerable to daily variations in $\mathrm{H}_{2} \mathrm{O}_{2}$ concentration in the natural environment. It has been demonstrated that this species possesses an alternative mechanism to deal with environmental $\mathrm{H}_{2} \mathrm{O}_{2}$ since it presents a conspicuous mucus secretion that protects its body against environmental $\mathrm{H}_{2} \mathrm{O}_{2}$ because of high CAT and GPx activities (17). However, during the experimental period the dishes containing the animals were cleaned daily, with the consequent removal of this protection.

The absence of the induction of activity of the antioxidant enzymes involved in $\mathrm{H}_{2} \mathrm{O}_{2}$ degradation was paralleled by an increase of almost $441 \%$ in LPO levels after 10 days of exposure to the higher $\mathrm{H}_{2} \mathrm{O}_{2}$ concentration $(50 \mu \mathrm{M}$; $\mathrm{P}<0.05$; Figure 2A). This result agrees with the reduction of CAT activity in the pellet fraction during the same period, suggesting oxidative damage at the protein level (18).

The oxygen consumption response was biphasic, decreasing after 4 days and increasing after 7 and 10 days of exposure to $50 \mu \mathrm{M} \mathrm{H}_{2} \mathrm{O}_{2}(\mathrm{P}<0.05$; Figure 2B). The hehavior of the first phase corroborates reports about Nereis diversicolor exposed for $6 \mathrm{~h}$ to $5 \mu \mathrm{M} \mathrm{H}_{2} \mathrm{O}_{2}$ (4), about the isolated body wall of Arenicola maritma (Polychaeta) exposed to $300 \mu \mathrm{M} \mathrm{H}_{2} \mathrm{O}_{2}$ (1) and about the shrimp Crangon crangon exposed for $5 \mathrm{~h}$ to $20 \mu \mathrm{M} \mathrm{H}_{2} \mathrm{O}_{2}$ (2). This decrease was related to damage to the membrane transporter mechanisms and to the consequent reduction in intracellular $\mathrm{pH}$ (2).

The second phase response, to our knowledge, has not been reported in literature and we consider it to be a stress response that should increase the generation of reactive oxygen species (3). This fact plus exposure to $\mathrm{H}_{2} \mathrm{O}_{2}$ would lead to the oxidative damage situation observed at this time.

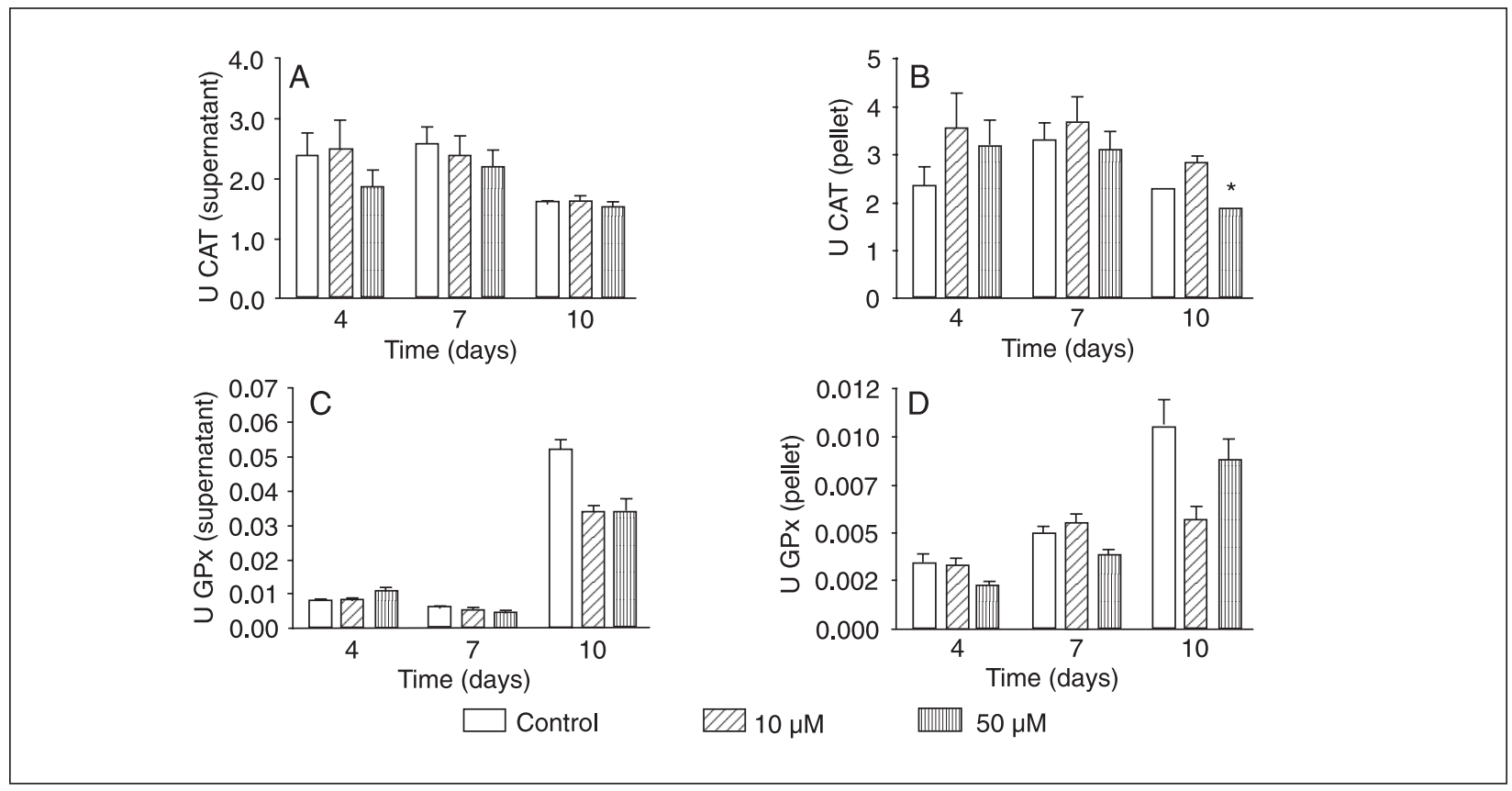

Figure 1. Catalase (CAT) activity (in units, $U$ ) in the supernatant $(A)$ and pellet (B) fraction of Laeonereis acuta homogenates after exposure to 0 (control), 10, or $50 \mu \mathrm{M}$ hydrogen peroxide. Glutathione peroxidase (GPx) activity (in units, $U$ ) in the supernatant (C) and pellet (D) fraction of $L$. acuta homogenates after exposure to 0 (control), 10 , or $50 \mu \mathrm{M}$ hydrogen peroxide. Data are reported as means $\pm \mathrm{SD}$ for $\mathrm{N}=5-9 .{ }^{*} \mathrm{P}<0.05$ compared to control (ANOVA and Newman-Keuls test). 


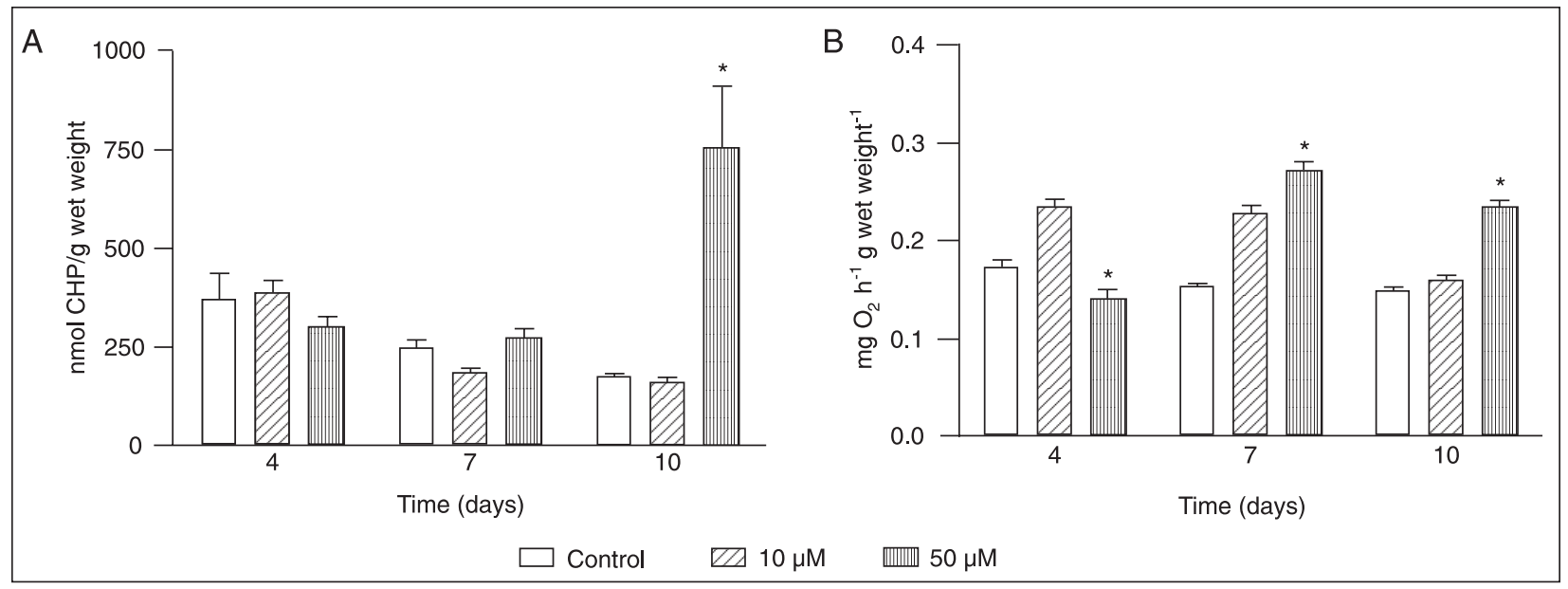

Figure 2. A, Lipid peroxide (LPO) content of Laeonereis acuta after exposure to 0 (control), 10 , or $50 \mu \mathrm{M}$ hydrogen peroxide. Units of LPO are in terms of cumene hydroperoxide (CHP) equivalents per gram wet weight $(\mathrm{w} / \mathrm{w})$. $B$, Oxygen consumption of $L$. acuta after exposure to 0 (control), 10 , or $50 \mu \mathrm{M}$ hydrogen peroxide. Units of oxygen consumption are reported as mg O $\mathrm{h}^{-1} \mathrm{~g}$ wet weight ${ }^{-1}$ (w/ w). Data are reported as means \pm SEM for $N=4-8$. ${ }^{*} P<0.05$ compared to control (ANOVA and Newman-Keuls test).

After the period of exposure to both concentrations of $\mathrm{H}_{2} \mathrm{O}_{2}$, morphological alterations were observed, similar to these described in the aquatic oligochaeta Tubifex tubifex after 96-h exposure to copper and lead (19) and in L. acuta chronically exposed to copper (6). Worms exposed to $\mathrm{H}_{2} \mathrm{O}_{2}$ showed coiling and necrosis, particularly in the posterior region of their body, where the cuticle is thinner than the other parts (5), with this region being more susceptible to the effects of $\mathrm{H}_{2} \mathrm{O}_{2}$.

The present study demonstrates that exposure to higher concentrations of $\mathrm{H}_{2} \mathrm{O}_{2}$ causes a significant alteration in the metabolism of $L$. acuta, as shown by the oxygen consumption measurements. It was also demonstrated that its antioxidant defense system was not sufficient to deal with $\mathrm{H}_{2} \mathrm{O}_{2}$ exposure, as evidenced by the oxidative damage and necrosis observed.

\section{References}

1. Storch D, Abele D, Portner HO. The effect of hydrogen peroxide on isolated body wall of the lugworm Arenicola marina (L.) at different extracellular pH levels. Comp Biochem Physiol C Toxicol Pharmacol 2001; 128: 391-399.

2. Abele-Oeschger D, Sartoris FJ, Pörtner HO. Hydrogen peroxide causes a decrease in aerobic metabolic rate and in intracellular $\mathrm{pH}$ in the shrimp Crangon crangon. Comp Biochem Physiol 1997; 117: 123-129.

3. Halliwel B, Gutteridge JM. Free radicals in biology and medicine. New York: Oxford University Press; 1998.

4. Buchner T, Abele-Oeschger D, Theede H. Biochemical adaptations of Nereis diversicolor (Polychaeta) to temporarily increased hydrogen peroxide levels in intertidal sandflats. Mar Ecol Prog Ser 1994; 106: 101-110.

5. da Rosa CE, Iurman MG, Abreu PC, Geracitano LA, Monserrat JM. Antioxidant mechanisms of the Nereidid Laeonereis acuta (Anelida: Polychaeta) to cope with environmental hydrogen peroxide. Physiol Biochem Zool 2005; 78: 641-649.

6. Geracitano LA, Bocchetti R, Monserrat JM, Regoli F, Bianchini A. Oxidative stress responses in two populations of Laeonereis acuta (Polychaeta, Nereididae) after acute and chronic exposure to copper. Mar Environ Res 2004; 58: $1-17$.

7. da Rosa CE, de Souza MS, Yunes JS, Proenca LA, Nery LE, Monserrat JM. Cyanobacterial blooms in estuarine ecosystems: characteristics and effects on Laeonereis acuta (Polychaeta, Nereididae). Mar Pollut Bull 2005; 50: 956964.

8. Sandrini JZ, Laurino J, Hatanaka T, Monserrat JM. cDNA cloning and expression analysis of the catalytic subunit of glutamate cysteine ligase gene in an annelid polychaete after cadmium exposure: a potential tool for pollution biomonitoring. Comp Biochem Physiol C Toxicol Pharmacol 2006; 143: 410-415.

9. Ferreira-Cravo M, Piedras FR, Moraes TB, Ferreira JL, de Freitas DP, Machado MD, et al. Antioxidant responses and reactive oxygen species generation in different body regions of the estuarine polychaeta Laeonereis acuta (Nereididae). Chemosphere 2007; 66: 1367-1374.

10. Geracitano L, Monserrat JM, Bianchini A. Physiological and antioxidant enzyme responses to acute and chronic exposure of Laeonereis acuta (Polychaeta, Nereididae) to copper. J Exp Mar Biol Ecol 2002; 277: 145-156. 
11. Nithart M, Alliot E, Salen-Picard C. Production, respiration and ammonia excretion of two polychaete species in a north Norfolk saltmarsh. J Mar Biol Ass U K 1999; 79: 1029-1037.

12. Cavaletto $M$, Ghezzi A, Burlando B, Evangelisti V, Ceratto $\mathrm{N}$, Viarengo $\mathrm{A}$. Effect of hydrogen peroxide on antioxidant enzymes and metallothionein level in the digestive gland of Mytilus galloprovincialis. cavalett@unipmn.it. Comp Biochem Physiol C Toxicol Pharmacol 2002; 131: 447-455.

13. Beutler $E$. The preparation of red cells for assay. In: Beutler E (Editor), Red cell metabolism: a manual of biochemical methods. New York: Grune \& Straton Editor; 1975. p 8-18.

14. Arun S, Subramanian P. Antioxidant enzymes in freshwater prawn Macrobrachium malcolmsonni during embryonic development. Comp Biochem Physiol 1998; 121: 273-277.

15. Sedlak J, Lindsay RH. Estimation of total, protein-bound, and nonprotein sulfhydryl groups in tissue with Ellman's reagent. Anal Biochem 1968; 25: 192-205.

16. Hermes-Lima M, Willmore WG, Storey KB. Quantification of lipid peroxidation in tissue extracts based on $\mathrm{Fe}(\mathrm{III}) x y l e n o l$ orange complex formation. Free Radic Biol Med 1995; 19: 271-280.

17. Moraes TB, Ferreira JL, da Rosa CE, Sandrini JZ, Votto AP, Trindade GS, et al. Antioxidant properties of the mucus secreted by Laeonereis acuta (Polychaeta, Nereididae): a defense against environmental pro-oxidants? Comp Biochem Physiol C Toxicol Pharmacol 2006; 142: 293-300.

18. Kono Y, Fridovich I. Superoxide radical inhibits catalase. $J$ Biol Chem 1982; 257: 5751-5754.

19. Lucan-Bouché ML, Biagianti-Risbourg S, Arsac F, Vernet G. An original decontamination process developed by the aquatic oligochaete Tubifex tubifex exposed to copper and lead. Aquat Toxicol 1999; 45: 9-17. 